\title{
平成28年 電気学会産業応用部門大会
}

2016 IEE-Japan Industry Applications Society Conference

大会開催案内と論文募集

Conference Information and Call for Papers

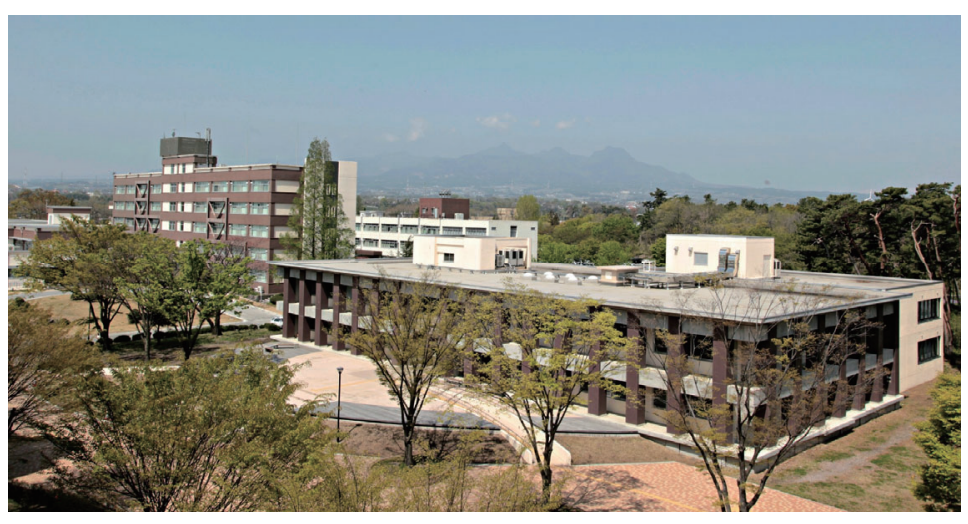

群馬大学 荒牧キャンパス

第 30 回産業応用部門大会を, 平成 28 年 8 月 30 日〜9月 1 日に前橋市で開催します。大会では, 一般セッション, ヤングエンジニアポスターコンペテ イション等を行います。投稿者は電気学会員および 協賛学会員に限ります。以下の要領で論文を募集 しますので, 奮って御応募いただきますようお願い いたします。

2016 IEE-Japan Industry Applications Society Conference will be held in August 30th to September 1st, 2016 at Gunma University, Maebashi, Gunma, Japan.

\section{会 期 平成28年8月30日(火) 9月1日(木) \\ 会 場 群馬大学 荒牧キャンパス(前橋市荒牧町4丁目2) \\ 論文募集}

ロ 一般セッション

論文を日本語または英語で発表討論するもので, 本大会はオーラルセッションのみ実施します。

(日本語論文: 2 ページ, 4 ページ, 6 ページ , 英語論文: 4 ページ, 6 ページ※)

— ヤングエンジニアポスターコンペティション (YPC)

卒業研究や大学院での研究成果, あるいは企業における研究で, 本人が中心となって行った未発表のものに限ります。 (日本語論文, 英語論文: 1 ページ)

ロオーガナイズドセッション 新たな分野や最新の技術に関してより活発な討論を行うため, オーガナイザーにより企画されたセッションです。 (日本語論文, 英語論文: 4 ページ, 6 ページ※)

※6ページの論文は電気学会産業応用部門誌に投稿できる完成度の論文に限ります。

\section{論文締切(予定)：平成28年5月13日(金)}

問い合わせ先

平成 28 年電気学会産業応用部門大会事務局

厂 376-8515 群馬県桐生市天神町1-5-1 群馬大学理工学部電子情報理工学科

石川 赴夫 (実行委員会委員長), 栗田 伸幸 (実行委員会幹事), 廣塚 功 (論文委員長)

TEL: 0277-30-1752 FAX: 0277-30-1707 E-mail: iasc2016 (at) ml.gunma-u.ac.jp

General Information

Contact Information

Steering Committee

Chair

Takeo ISHIKAWA

Gunma University

Date: August 30 (Tue.) - September 1 (Thu.), 2016

Venue: Gunma University, Maebashi, Gunma, Japan

\section{Deadline for paper submission is May 13, 2016}

JIASC2016 Secretariat

Division of Electronics and Informatics

Faculty of Science and Technology, Gunma University

1-5-1 Tenjin, Kiryu, Gunma, 376-8515, Japan

TEL: +81-277-30-1752 FAX: +81-277-30-1707 E-mail: iasc2016 (at) ml.gunma-u.ac.jp

\section{Secretary}

Nobuyuki KURITA

Gunma University
Technical Program Committee

Isao HIROTSUKA

Chubu University 